\title{
Unable to Classify
}

National Cancer Institute

\section{Source}

National Cancer Institute. Unable to Classify. NCI Thesaurus. Code C154423.

An inability to assign something to the existing classifications or categories. 